\title{
FAKTOR-FAKTOR YANG BERPENGARUH TERHADAP PENDAPATAN DAN PRODUKTIVITAS AGROINDUSTRI GULA KELAPA DI KABUPATEN PANGANDARAN
}

\author{
FACTORS THAT INFLUENCE THE INCOME AND PRODUCTIVITY OF \\ COCONUT SUGAR AGROINDUSTRY IN PANGANDARAN DISTRICT
}

\author{
Fitri Yuroh*, Ida Maesaroh \\ Fakultas Pertanian, Universitas Galuh \\ *E-mail: fitriyuroh3@gmail.com \\ (Diterima 18-07-2018; Disetujui 27-07-2018)
}

\begin{abstract}
ABSTRAK
Tujuan penelitian ini adalah untuk mengetahui: (1) Pendapatan agroindustri gula kelapa dan faktor-faktor yang mempengaruhinya, dan (2) Produktivitas yang dicapai pada agroindustri gula kelapa dan faktor-faktor yang mempengaruhinya. Penelitian dilaksanakan dengan menggunakan metode survai pada 100 agroindustri gula kelapa di Kabupaten Pangandaran. Pendapatan agroindustri gula kelapa didekati didekati dengan menggunakan analisis pendapatan, sedangkan produktivitas didekati dengan menggunakan produktivitas faktor total. Faktor-faktor yang mempengaruhi pendapatan dan produktivitas dianalisis dengan menggunakan persamaan regresi berganda. Hasil penelitian menunjukkan: (1) Biaya total agroindustri gula kelapa di Kabupaten Pangandaran sebesar Rp 85.135,39, penerimaan Rp 113.232,00, dan pendapatan Rp 28.096,61. Jumlah produksi, modal, pendidikan, kredit, dan penyuluhan berpengaruh signifikan terhadap pendapatan agroindustri gula kelapa, dan (2) Produktivitas faktor total yang dicapai pada agroindustri gula kelapa di Kabupaten Pangandaran berkisar antara 0,60-3,12, dengan rata-rata sebesar 1,52. Biaya produksi, pendidikan, pengalaman, ukuran keluarga, kredit, dan penyuluhan berpengaruh signifikan terhadap produktivitas yang dicapai pada agroindustri gula kelapa.
\end{abstract}

Kata kunci: Gula Kelapa, Pendapatan, Produktivitas Faktor Total

\begin{abstract}
The purpose of this research is to know: (1) Income of coconut sugar agroindustry and its influencing factors, and (2) Productivity achieved in coconut sugar agroindustry and its influencing factors. The research was conducted by using survey method on 100 coconut sugar agroindustries in Pangandaran District. Coconut sugar agroindustry income is approached by using income analysis, while productivity is approximated by using total factor productivity. Factors affecting income and productivity were analyzed by using multiple regression equation. The results showed: (1) The total cost of coconut sugar agroindustry in Pangandaran Regency was Rp 85,135.39, Rp 113,232.00 in revenue, and $\mathrm{Rp} 28,096.61$ in income. Total production, capital, education, credit, and extension have significant effect to coconut sugar agroindustry income, and (2) Total factor productivity achieved at coconut sugar agroindustry in Pangandaran District ranged from 0.60 to 3.12, with an average of 1.52. Production costs, education, experience, family size, credit, and extension have a significant effect on the productivity achieved in coconut sugar agroindustry.
\end{abstract}

Keywords: Coconut Sugar, Income, Total Factor Productivity 


\section{PENDAHULUAN}

Agroindustri gula kelapa saat ini mempunyai prospek yang cukup bagus dan diharapkan mampu meningkatkan pendapatan rumah tangga pembuat gula merah itu sendiri dan masyarakat sekitar (Mugiono, dkk., 2014). Selain itu, potensi agroindustri gula kelapa juga terbuka lebar karena sifat produk yang selalu dibutuhkan (Maharani, dkk., 2011). Melalui pengembangan agroindustri kelapa diharapkan dapat meningkatkan pendapatan petani kelapa dan membuka lapangan kerja baru, yang pada gilirannya dapat meningkatkan pendapatan asli daerah (Budiarto, 2010).

Kecenderungan meningkatnya permintaan pasar terhadap produk-produk agroindustri serta tersedianya sumber daya alam yang cukup besar telah memberikan harapan bahwa agroindustri ini cukup prospektif dan memiliki potensi untuk menciptakan nilai tambah yang lebih besar terhadap setiap pelaku yang terlibat di dalam sistem. Di samping itu, pengembangan agroindustri ini akan secara langsung berpengaruh pada penciptaan lapangan kerja dan pemerataan pendapatan (Anonim, 2010 dalam Evalia, 2015, Darma, et al, 2015).
Sebagai industri rumah tangga, agroindustri gula kelapa ini memiliki ciri teknologi yang relatif sederhana, padat karya dan produksi tidak bergantung pada permintaan pasar tetapi berdasarkan ketersediaan bahan baku (Maharani, dkk., 2011). Perajin gula kelapa umumnya memiliki keterbatasan dalam mengakses pasar dan mendapatkan bagian nilai mata rantai yang rendah dalam proses bisnis komoditi gula kelapa. Hal ini disebabkan karena pengetahuan para perajin gula kelapa pada umumnya masih rendah, tradisional, dan belum memiliki jiwa kewirausahaan. Kesulitan umum yang dihadapi oleh para perajin gula kelapa adalah permodalan, teknik berproduksi, manajemen usaha dan jaringan pemasaran (Supomo, 2007). Pada prinsipnya, agroindustri yang ada berskala kecil dan dikelola secara individu dengan teknologi yang diwariskan secara turun temurun (Aliudin, dkk., 2011), serta adanya hambatan teknis dan non teknis, seperti rendahnya keterampilan petani, rendahnya hasil produksi dan nilai tambah (Rachman, 2009).

Tujuan penelitian ini adalah untuk mengetahui: (1) Pendapatan agroindustri gula kelapa di Kabupaten Pangandaran 
dan faktor-faktor yang mempengaruhinya, dan (2) Produktivitas yang dicapai pada agroindustri gula kelapa di Kabupaten Pangandaran dan faktor-faktor yang mempengaruhinya.

\section{TINJAUAN PUSTAKA}

Gula kelapa merupakan salah satu dari sembilan bahan pokok kebutuhan pangan yang banyak diperlukan sebagai campuran bumbu masakan, pemanis masakan dan bahan campuran dalam pembuatan kue. Usaha pembuatan gula kelapa ini merupakan industri rumah tangga yang menemui kendala berupa teknologi pengolahan yang kurang berkembang serta keterbatasan dalam pemasaran yang mengakibatkan produksi gula kelapa kurang optimal dan berpengaruh terhadap besarnya keuntungan dan efisiensi usaha serta kemungkinan risiko yang akan dihadapi oleh produsen. Industri gula kelapa ini sangat dipengaruhi oleh adanya perbedaan musim, yaitu pada musim penghujan dan musim kemarau. Gula kelapa yang dihasilkan pada musim penghujan jumlah produksinya lebih tinggi dibandingkan saat musim kemarau, namun memiliki harga jual yang lebih rendah. Fluktuasi harga gula kelapa ini merupakan salah satu risiko yang dihadapi produsen dalam kegiatan usahanya (Muhroil, dkk., 2015).

Suatu usaha pada dasarnya bertujuan sama, yaitu memperoleh pendapatan semaksimal mungkin, namun faktor produksi dapat menjadi kendala dalam memperoleh pendapatan tersebut yang berkaitan dengan efisiensi produksi (Rusmiati, dkk., 2011). Pendapatan dalam suatu usaha adalah pendapatan yang diperoleh karena telah mengorganisasikan seluruh faktor produksi yang dimiliki (Butarbutar, 2017).

Pendapatan perajin gula kelapa terbagi menjadi dua, yaitu pendapatan kotor (penerimaan) dan pendapatan bersih (keuntungan). Pendapatan kotor atau penerimaan adalah nilai produk total dalam jangka waktu tertentu baik yang dijual maupun yang tidak dijual yang dihitung dengan cara mengalikan jumlah produk fisik dengan harga. Jadi besarnya pendapatan kotor tergantung pada besar kecilnya produksi dengan tingkat harga yang berlaku. Sedangkan pendapatan bersih adalah selisih antara pendapatan kotor dengan biaya total produksi (Martono, dkk., 2007). 
Pendapatan merupakan hasil yang diperoleh perajin dari selisih antara penerimaan total dengan biaya total selama proses produksi (Saleh, 2014). Setiap kegiatan usaha bertujuan untuk memperoleh pendapatan yang maksimal sehingga kelangsungan hidup usaha tersebut tetap terjaga (Triastono, dkk., 2013). Beberapa penelitian menunjukkan bahwa variabel yang berpengaruh signifikan terhadap pendapatan adalah: jumlah produksi, harga, rendeman dan jumlah batang sadapan (Batubara, dkk., 2014); pengalaman, hasil produksi per hektar dan jarak dari lokasi usahatani ke pabrik (Masuku, 2011); jumlah nira kelapa, modal dan tenaga kerja (Khasanah, 2007 dalam Rizieq, 2009); pendidikan formal, jaringan hubungan sosial dan modal (Mumu, 2015); jumlah produksi (Setiawan, 2012).

Ukuran produktivitas ada dua, yaitu produktivitas parsial dan produktivitas faktor total. Produktivitas faktor total merupakan produktivitas yang mengukur semua faktor yang digunakan dalam produksi. Pengukuran tradisional lain dari produktivitas, seperti produktivitas tenaga kerja, sering disebut sebagai produktivitas parsial (Nadiri, 1970).
Produktivitas dipengaruhi oleh faktor internal maupun eksternal. Faktor internal yang utama adalah kemampuan petani dalam mengelola usahataninya yang ditentukan oleh beberapa hal, antara lain tingkat pendidikan, pengalaman, tingkat pengetahuan dan keterampilan petani. Faktor internal lainnya adalah ukuran usahatani (size of farm) berupa luas lahan (Rachmina, et al, 2012).

Produktivitas merupakan rasio keluaran yang diproduksi terhadap masukan yang digunakan (Coelli, et al, 2005). Beberapa penelitian mengenai faktor-faktor yang berpengaruh terhadap produktivitas adalah: penyuluhan (Onumah, et al, 2013); biaya produksi dan pengalaman (Bakhri, 2016); tenaga kerja, modal dan teknologi (Ariani dan Suresmiathi, 2013).

\section{METODE PENELITIAN}

Jenis penelitian yang digunakan dalam penelitian ini adalah penelitian survai. Menurut Singarimbun (1989), penelitian survai adalah penelitian yang mengambil sampel dari satu populasi dan menggunakan kuesioner sebagai alat pengumpulan data yang pokok.

Data yang digunakan dalam penelitian ini terdiri atas data primer dan 
data sekunder. Data primer diperoleh melalui wawancara dengan menggunakan kuesioner yang telah dipersiapkan sebelumnya, dan terdiri atas karakteristik individu perajin gula kelapa dan data produksi. Sedangkan data sekunder diperoleh melalui penelusuran referensi maupun publikasi dari dinas atau instansi terkait.

Kabupaten Pangandaran terdiri atas 10 kecamatan, yaitu kecamatan Parigi, Cigugur, Cijulang, Cimerak, Kalipucang, Langkaplancar, Mangunjaya, Padaherang, Pangandaran, dan Sidamulih. Keseluruhan kecamatan tersebut memiliki agroindustri gula kelapa, sehingga diambil seluruhnya sebagai sampel wilayah. Dari masingmasing kecamatan tersebut diambil 10 agroindustri gula kelapa, sehingga ukuran sampel sebanyak 100 agroindustri.

Analisis biaya, penerimaan dan pendapatan agroindustri gula kelapa didekati dengan menggunakan analisis pendapatan dari Suratiyah (2006):

(1) Analisis Biaya

$\mathrm{TC}=\mathrm{TFC}+\mathrm{TVC}$

Dimana:

$\mathrm{TC}=$ Total Cost

TFC $=$ Total Fixed Cost

TVC $=$ Total Variable Cost
(2) Analisis Penerimaan

$\mathrm{TR}=\mathrm{Y} . \mathrm{Hy}$

Dimana:

TR $=$ Penerimaan total

$\mathrm{Y}=$ Jumlah produk

Hy = Harga jual produksi

(3) Analisis Pendapatan

$\pi=\mathrm{TR}-\mathrm{TC}$

Dimana:

$\pi=$ Pendapatan

$\mathrm{TR}=$ Penerimaan total

$\mathrm{TC}=$ Biaya total

Faktor-faktor yang berpengaruh terhadap pendapatan agroindustri gula kelapa dilakukan dengan menggunakan persamaan regresi berganda dengan model sebagai berikut:

$$
\begin{aligned}
Y= & a+b_{1} X_{1}+b_{2} X_{2}+b_{3} X_{3}+b_{4} X_{4}+b_{5} X_{5} \\
& +b_{6} X_{6}+b_{7} X_{7}+b_{8} D_{1}+b_{9} D_{2}
\end{aligned}
$$

Dimana:

$\mathrm{Y}=$ Pendapatan (Rp/bulan)

$\mathrm{X}_{1}=$ Jumlah produksi $(\mathrm{kg})$

$\mathrm{X}_{2}=$ Modal (Rp/bulan)

$\mathrm{X}_{3}=$ Umur (tahun)

$\mathrm{X}_{4}=$ Pendidikan (tahun)

$\mathrm{X}_{5}=$ Pengalaman (tahun)

$\mathrm{X}_{6}=$ Ukuran keluarga (orang)

$\mathrm{D}_{1}=$ Dummy kredit, bernilai 1 jika Iya, bernilai 0 jika Tidak

$\mathrm{D}_{2}=$ Dummy penyuluhan, bernilai 1 jika Iya, bernilai 0 jika Tidak

$\mathrm{b}_{1-9}=$ Koefisien regresi

Pendugaan parameter dengan menggunakan program SPSS versi 16.

Produktivitas didekati dengan Produktivitas Faktor Total (Total Factor Productivity, TFP). Jika output 
perusahaan dinotasikan dengan $\mathrm{q}$ atau vektor output, harga output dengan $p$ atau vektor harga output, input dengan $\mathrm{x}$ atau vektor input, dan harga input dengan $\mathrm{w}$ sebagai vektor harga input, maka profitabiltas dapat dirumuskan sebagai berikut (Coelli, et al, 2005):

$$
\begin{aligned}
& \pi_{1}=\frac{p_{1}^{\prime} q_{1}}{w_{1}^{\prime} x_{1}}=\frac{\sum_{m=1}^{M} p_{m 1} q_{m 1}}{\sum_{k=1}^{K} w_{k 1} x_{k 1}} \\
& \text { Dalam penelitian ini yang }
\end{aligned}
$$
dianalisis adalah agroindustri gula kelapa, sehingga output (q) yang diperhitungkan adalah jumlah produksi gula kelapa yang diukur dalam satuan kilogram. Sedangkan input yang digunakan meliputi:

$\mathrm{x}_{1}=$ Jumlah nira yang disadap, diukur dalam satuan liter (liter)

$\mathrm{x}_{2}=$ Parutan kelapa, diukur dalam satuan kubik (kubik)

$\mathrm{x}_{3}=$ Kayu bakar, yang diukur dalam satuan kilogram $(\mathrm{kg})$

$\mathrm{x}_{4}=$ Natrium bisulfat, diukur dalam satuan kilogram $(\mathrm{kg})$

$\mathrm{x}_{5}=$ Tenaga kerja, diukur dalam satuan hari kerja setara pria (HKSP)

$\mathrm{p}=$ Harga output yang diukur dalam satuan rupiah per kilogram $(\mathrm{Rp} / \mathrm{kg})$

$\mathrm{w}=$ Harga input, yang diukur dalam satuan rupiah per liter (Rp/liter), rupiah per kubik (Rp/kubik), rupiah per kilogram $(\mathrm{Rp} / \mathrm{kg})$, dan rupiah per HKSP (Rp/HKSP)

Pengukuran produktivitas dengan menggunakan program TFPIP versi 1.0.
Faktor-faktor yang berpengaruh terhadap produktivitas usaha gula kelapa dianalisis dengan menggunakan persamaan regresi linier berganda sebagai berikut:

$$
\begin{aligned}
Y= & b_{0}+b_{1} V_{1}+b_{2} V_{2}+b_{3} V_{3}+b_{4} V_{4} \\
& +b_{5} V_{5}+b_{6} V_{6}+b_{7} D_{1}+b_{8} D_{1}
\end{aligned}
$$

Dimana:

$\mathrm{Y}=$ Produktivitas

$\mathrm{V}_{1}=$ Biaya produksi (Rp)

$\mathrm{V}_{2}=$ Umur (tahun)

$\mathrm{V}_{3}=$ Pendidikan (tahun)

$\mathrm{V}_{4}=$ Pengalaman beternak (tahun)

$\mathrm{V}_{5}=$ Ukuran keluarga (orang)

$\mathrm{D}_{1}=$ Dummy kredit, bernilai 1 jika Iya, bernilai 0 jika Tidak

$\mathrm{D}_{2}=$ Dummy penyuluhan, bernilai 1 jika Iya, bernilai 0 jika Tidak

$b_{1-8}=$ Koefisien regresi

Pendugaan parameter dengan menggunakan program SPSS versi 16.

Pengujian faktor-faktor yang mempengaruhi produktivitas dan pendapatan secara simultan dilakukan dengan menggunakan uji-F, sedangkan secara parsial dilakukan dengan menggunakan uji-t; dengan penjabaran sebagai berikut:

(1) Pengujian secara simultan dilakukan dengan menggunakan uji-F. Pengujian dilakukan terhadap hipotesis: $\mathrm{H}_{0}: \beta_{1}=\beta_{2}=\ldots=\beta_{\mathrm{i}}=0$. Hipotesis diterima jika nilai statistik F-hitung lebih kecil atau sama dengan F-tabel, berarti variabel 
bebas secara simultan tidak berpengaruh signifikan terhadap variabel terikat. Jika nilai statistik Fhitung lebih besar dari F-tabel, maka hipotesis ditolak yang menunjukkan bahwa variabel bebas secara simultan berpengaruh signifikan terhadap variabel terikat.

(2) Pengujian secara parsial dilakukan dengan menggunakan uji-t. Pengujian dilakukan terhadap hipotesis: $\mathrm{H}_{0}: \beta_{\mathrm{i}}=0$. Hipotesis diterima jika nilai statistik t-hitung lebih kecil atau sama dengan t-tabel, berarti variabel bebas secara parsial tidak berpengaruh signifikan terhadap variabel terikat. Jika nilai statistik t-hitung lebih besar dari ttabel, maka hipotesis ditolak yang menunjukkan bahwa variabel bebas secara parsial berpengaruh signifikan terhadap variabel terikat.

\section{HASIL DAN PEMBAHASAN}

\section{Karakteristik Responden}

Karakteristik responden penelitian meliputi umur, pendidikan, pengalaman, ukuran keluarga, jenis kelamin, penyuluhan dan kredit. Data selengkapnya mengenai karakteristik responden dapat dilihat pada Tabel 1 .

\section{Tabel 1. Karakteristik Responden}

\begin{tabular}{clcccc}
\hline No & Karakteristik & Satuan & Uraian & Jumlah (orang) & $\%$ \\
\hline 1 & Umur & tahun & $15-64$ & 95 & 95,00 \\
& & & $>64$ & 5 & 5,00 \\
\hline 2 & Pendidikan & tahun & SD & 82 & 82,00 \\
& & & SMP & 14 & 14,00 \\
& & & SMA & 4 & 4,00 \\
\hline 3 & \multirow{2}{*}{ Pengalaman } & tahun & $1-10$ & 33 & 33,00 \\
& & & $11-20$ & 36 & 36,00 \\
& & & $21-30$ & 17 & 17,00 \\
& & & $31-40$ & 8 & 8,00 \\
& & & $41-50$ & 6 & 6,00 \\
\hline 4 & Ukuran keluarga & orang & $1-4$ & 68 & 68,00 \\
& & & $5-8$ & 32 & 32,00 \\
\hline
\end{tabular}

Sumber: Analisis data primer, 2018

Tabel 1 menunjukkan bahwa sebagian besar pelaku agroindustri gula kelapa di Kabupaten Pangandaran berada pada kategori usia produktif (15-64 tahun), yaitu sebanyak 95 orang $(95,00 \%)$. Menurut Putri dan Setiawina (2013), umur produktif berkisar antara 15-64 tahun yang merupakan umur ideal 
bagi para pekerja. Di masa produktif, secara umum semakin bertambahnya umur maka pendapatan akan semakin meningkat, yang tergantung juga pada jenis pekerjaan yang dilakukan. Kekuatan fisik seseorang untuk melakukan aktivitas sangat erat kaitannya dengan umur karena bila umur seseorang telah melewati masa produktif, maka semakin menurun kekuatan fisiknya sehingga produktivitasnya pun menurun dan pendapatan juga ikut turun.

Sebagian besar responden berpendidikan setingkat sekolah dasar (SD), yaitu sebanyak 82 orang $(82 \%)$. Menurut Nazamuddin (2013), kuantitas dan kualitas pendidikan diyakini menentukan efisiensi dan produktivitas perekonomian. Semakin tinggi jumlah tenaga kerja yang terdidik dan terampil, semakin produktif suatu masyarakat. Di samping itu, terdapat hubungan positif antara kinerja pendidikan dengan pertumbuhan ekonomi yang diindikasikan dengan kenaikan pertumbuhan ekonomi, pendapatan per kapita, dan penurunan angka pengangguran.

Menurut Purwanto (2006), aspek pendidikan dianggap memiliki peranan paling penting dalam menentukan kualitas manusia. Karena melalui pendidikan, manusia dianggap akan memperoleh pengetahuan, dan dengan pengetahuannya manusia diharapkan dapat membangun keberadaan hidupnya dengan lebih baik sehingga kita mengenal kurikulum berbasis kompetensi dan atau life skills. Secara rasional dapat dikatakan bahwa semakin tinggi tingkat pendidikan seseorang maka kualitas hidup manusia akan semakin baik, karena dengan ilmu pengetahuannya ia dapat mengelola dirinya sendiri. Dalam lingkup makro ekonomi atau dengan perekonomian secara umum (nasional), semakin tinggi kualitas hidup suatu bangsa, semakin tinggi tingkat pertumbuhan dan kesejahteraan bangsa tersebut.

Sebagian besar responden memiliki pengalaman dalam mengelola agroindustri gula kelapa 1-10 tahun (33 orang) dan 11-20 tahun (36 orang). Menurut Manulang (2005), pengalaman merupakan proses pembentukan pengetahuan dan keterampilan tentang metode suatu pekerjaan karena keterlibatannya dalam pelaksanaan pekerjaannya. Pengalaman kerja merupakan faktor yang paling mempengaruhi dalam terciptannya pertumbuhan suatu usaha. 
Sebagian besar responden memiliki ukuran keluarga 1-4 orang, yaitu 68 orang $(68,00 \%)$. Menurut Kiranasari (2011), jumlah tanggungan keluarga merupakan faktor yang mempengaruhi kemauan seseorang untuk melakukan pekerjaan. Karena semakin banyak jumlah tanggungan keluarga responden, maka waktu yang disediakan responden untuk bekerja semakin efektif. Efektivitas waktu ini berguna untuk meningkatkan jumlah jam kerja agar dapat meningkatkan jumlah jam kerja agar dapat meningkatkan penghasilan responden. Di dalam penelitian ini, jumlah tanggungan keluarga juga mempengaruhi curahan jam kerja, karena jika jumlah anak dan tanggungan semakin besar, maka biaya yang dikeluarkan untuk kebutuhan sehari-hari juga semakin tinggi dan biaya sekolah yang relatif mahal.

\section{Pendapatan Agroindustri Gula Kelapa}

Pendapatan agroindustri gula kelapa di Kabupaten Pangandaran dihitung dengan cara mengurangkan penerimaan dengan biaya yang dikeluarkan. Selengkapnya mengenai perhitungan pendapatan agroindustri gula kelapa dapat dilihat pada Tabel 2.

Tabel 2. Pendapatan Agroindustri Gula Kelapa

\begin{tabular}{clcrr}
\hline No & \multicolumn{1}{c}{ Uraian } & Satuan & Jumlah $(\mathrm{Rp})$ & \multicolumn{1}{c}{ (\%) } \\
\hline 1. & Biaya tetap total & $\mathrm{Rp}$ & $31.821,06$ & 37,38 \\
& a. Pajak bumi dan bangunan & $\mathrm{Rp}$ & 2,58 & 0,00 \\
& b. Penyusutan alat & $\mathrm{Rp}$ & $2.375,56$ & 2,79 \\
& c. Sewa pohon & $\mathrm{Rp}$ & $21.590,40$ & 25,36 \\
& d. Bunga modal & $\mathrm{Rp}$ & $7.852,51$ & 9,22 \\
\hline 2. & Biaya variabel total & $\mathrm{Rp}$ & $53.314,33$ & 62,62 \\
& a. Natrium bisulfat & $\mathrm{Rp}$ & $1.254,00$ & 1,50 \\
& b. Kayu bakar & $\mathrm{Rp}$ & $12.248,00$ & 14,39 \\
& c. Plastik & $\mathrm{Rp}$ & 500,00 & 0,59 \\
& d. Parutan kelapa & $\mathrm{Rp}$ & 829,50 & 0,97 \\
& e. Kapur sirih & $\mathrm{Rp}$ & 306,40 & 0,36 \\
& f. Tenaga kerja & $\mathrm{Rp}$ & $25.000,00$ & 29,36 \\
& g. Bunga modal & $\mathrm{Rp}$ & $13.156,43$ & 15,45 \\
\hline 3. & Biaya total & $\mathrm{Rp}$ & $85.135,39$ & 100,00 \\
\hline 4. & Penerimaan & $\mathrm{Rp}$ & $113.232,00$ & \\
& a. Produksi & $\mathrm{Kg}$ & 9,44 & \\
& b. Harga jual & $\mathrm{Rp} / \mathrm{Kg}$ & $12.000,00$ & \\
\hline 5. Pendapatan & $\mathrm{Rp}$ & $28.096,61$ & \\
\hline 6. & R/C & & 1,33 & \\
\hline
\end{tabular}

Sumber: Analisis Data Primer, 2018 
Tabel 2 menunjukkan bahwa biaya tetap total sebesar $\mathrm{Rp} 31.821,06$ atau $37,38 \%$ dari seluruh biaya yang dikeluarkan dalam agroindustri gula kelapa. Sedangkan biaya variabel total sebesar Rp 53.314,33 atau 62,62\% dari seluruh biaya yang dikeluarkan. Biaya tetap total terdiri atas biaya pajak bumi dan bangunan $\operatorname{Rp} 2,58 \quad(0,00 \%)$, penyusutan alat $\operatorname{Rp} 2.375,56$ (2,79\%), sewa pohon $\operatorname{Rp} 21.590,40(25,36 \%)$, dan bunga modal Rp 7.852,51 (9,22\%). Hasil ini menunjukkan bahwa biaya untuk sewa pohon relatif besar sehingga perlu dipertimbangkan subsidi input bahan baku dalam proses produksi gula kelapa.

Biaya variabel total terdiri atas biaya pembelian natrium bisulfat $\mathrm{Rp}$ $1.254,00$ (1,50\%), kayu bakar Rp 12.248,00 (14,39\%), plastik Rp 500,00 $(0,59 \%)$, parutan kelapa Rp 829,50 (0,97\%), kapur sirih Rp 306,40 (0,36\%), tenaga kerja Rp 25.000 (29,36\%), dan bunga modal Rp 13.156,43 (15,45\%). Hasil ini menunjukkan bahwa biaya tenaga kerja dan bunga modal merupakan komponen biaya yang relatif besar sehingga perlu dipertimbangkan adanya kebijakan penurunan tingkat suku bunga dengan memberikan bantuan kredit program kepada pelaku agrobisnis gula kelapa.

Penerimaan agrobisnis gula kelapa $\mathrm{Rp}$ 113.232,00 yang diperoleh dari penjualan gula kelapa $9,44 \mathrm{~kg}$ dengan harga jual Rp 12.000. Dengan demikian, pendapatan agroindustri gula kelapa Rp 28.096,61 yang menunjukkan bahwa agroindustri merupakan salah satu jenis agroindustri yang berpotensi untuk peningkatan kesejahteraan pelaku agroindustri gula kelapa sehingga perlu dipertimbangkan adanya bantuan kredit program dalam upaya peningkatan skala produksi.

\section{Faktor-faktor yang Berpengaruh Terhadap Pendapatan Agroindustri Gula Kelapa}

Analisis faktor-faktor yang berpengaruh terhadap pendapatan agroindustri gula kelapa di Kabupaten Pangandaran dilakukan dengan menggunakan persamaan regresi linier berganda dimana estimasi parameter dilakukan dengan menggunakan SPSS versi 16. Hasil analisis faktor-faktor yang berpengaruh terhadap pendapatan agroindustri gula kelapa dapat dilihat pada Tabel 3. 
Tabel 3. Faktor-faktor yang Berpengaruh Terhadap Pendapatan

\begin{tabular}{lccc}
\hline \multicolumn{1}{c}{ Variabel } & Nilai parameter & Standar deviasi & t-hitung \\
\hline Konstanta & 43,042 & 1,925 & $22,360^{*}$ \\
Jumlah produksi $\left(\mathrm{X}_{1}\right)$ & 4,980 & 0,202 & $24,643^{*}$ \\
Modal $\left(\mathrm{X}_{2}\right)$ & $-3,780$ & 0,199 & $-18,997^{*}$ \\
Umur $\left(\mathrm{X}_{3}\right)$ & $-0,083$ & 0,127 & $-0,655$ \\
Pendidikan $\left(\mathrm{X}_{4}\right)$ & $-0,404$ & 0,110 & $-3,684^{*}$ \\
Pengalaman $\left(\mathrm{X}_{5}\right)$ & 0,018 & 0,032 & 0,564 \\
Ukuran keluarga $\left(\mathrm{X}_{6}\right)$ & $-0,063$ & 0,052 & $-1,204$ \\
Kredit $\left(\mathrm{X}_{7}\right)$ & $-0,340$ & 0,077 & $-4,398^{*}$ \\
Penyuluhan $\left(\mathrm{X}_{8}\right)$ & $-0,160$ & 0,078 & $-2,046^{* *}$ \\
\hline
\end{tabular}

$\mathrm{R}^{2}=0,958$

F-hit $=257,577^{*}$

Sumber: Analisis Data Primer, 2018

Keterangan: $* * * * * *=$ signifikansi pada $1 \%, 5 \%, 10 \%$

Tabel 3 menunjukkan nilai $\mathrm{R}^{2}$ sebesar 0,958 yang mengindikasikan bahwa variasi perubahan nilai pendapatan agroindustri gula kelapa dipengaruhi sebesar $95,80 \%$ oleh variasi perubahan nilai variabel-variabel bebas yang dimasukkan ke dalam model; sedangkan sisanya sebesar 4,20\% dipengaruhi oleh variabel lain yang tidak dimasukkan ke dalam model.

Pengujian secara simultan dengan menggunakan uji $\mathrm{F}$ menunjukkan bahwa variabel jumlah produksi $\left(\mathrm{X}_{1}\right)$, modal $\left(\mathrm{X}_{2}\right)$, umur $\left(\mathrm{X}_{3}\right)$, pendidikan $\left(\mathrm{X}_{4}\right)$, pengalaman $\left(\mathrm{X}_{5}\right)$, ukuran keluarga $\left(\mathrm{X}_{6}\right)$, kredit $\left(\mathrm{X}_{7}\right)$, dan penyuluhan $\left(\mathrm{X}_{8}\right)$ berpengaruh signifikan terhadap pendapatan agroindustri gula kelapa.

Pengujian secara parsial dengan menggunakan uji t menunjukkan bahwa variabel jumlah produksi $\left(\mathrm{X}_{1}\right)$, modal $\left(\mathrm{X}_{2}\right)$, pendidikan $\left(\mathrm{X}_{4}\right)$, kredit $\left(\mathrm{X}_{7}\right)$, dan penyuluhan $\left(\mathrm{X}_{8}\right)$ berpengaruh signifikan terhadap pendapatan agroindustri gula kelapa. Sedangkan variabel umur $\left(\mathrm{X}_{3}\right)$, pengalaman $\left(\mathrm{X}_{5}\right)$, dan ukuran keluarga $\left(\mathrm{X}_{6}\right)$ tidak berpengaruh signifikan terhadap pendapatan agroindustri gula kelapa.

Jumlah produksi $\left(\mathrm{X}_{1}\right)$ berpengaruh signifikan terhadap pendapatan agroindustri gula kelapa. Koefisiensi regresi bertanda positif menunjukkan bahwa peningkatan jumlah produksi akan meningkatkan pendapatan agroindustri gula kelapa. Hasil penelitian ini sesuai dengan hasil penelitian dari Setiawan (2012), Khotimah, dkk. (2014) dan Batubara, dkk. (2014). Peningkatan jumlah produksi berdampak pada 
peningkatan penerimaan sehingga terjadi peningkatan pendapatan pada agroindustri gula kelapa, ceteris paribus.

Modal $\left(\mathrm{X}_{2}\right)$ berpengaruh signifikan terhadap pendapatan agroindustri gula kelapa. Koefisiensi regresi bertanda negatif menunjukkan bahwa peningkatan modal akan menurunkan pendapatan agroindustri gula kelapa. Hasil penelitian ini sesuai dengan hasil penelitian dari Khasanah (2007) dalam Rizieq (2009), Mumu (2015) dan Butarbutar (2017). Peningkatan modal berdampak pada peningkatan skala produksi sehingga terjadi peningkatan jumlah produksi dan penerimaan. Selain itu, peningkatan skala produksi juga berdampak pada peningkatan biaya produksi. Jika peningkatan biaya produksi tidak diimbangi dengan peningkatan kemampuan teknis produksi dan manajemen, maka peningkatan penerimaan lebih rendah dibandingkan dengan peningkatan biaya produksi sehingga pendapatan akan menurun.

Umur $\left(\mathrm{X}_{3}\right)$ tidak berpengaruh signifikan terhadap pendapatan agroindustri gula kelapa. Koefisiensi regresi bertanda negatif menunjukkan bahwa peningkatan umur akan menurunkan pendapatan agroindustri gula kelapa. Hasil penelitian ini sesuai dengan hasil penelitian Putri dan Setiawina (2013). Umur berkaitan dengan kekuatan fisik dan kemampuan menganalisa proses produksi. Dengan demikian, peningkatan umur akan menurunkan kekuatan fisik dan kemampuan menganalisa proses produksi sehingga penerimaan mengalami penurunan yang berpengaruh terhadap penurunan pendapat.

Pendidikan formal berpengaruh signifikan terhadap pendapatan agroindustri gula kelapa. Koefisiensi regresi bertanda negatif menunjukkan bahwa peningkatan pendidikan formal akan menurunkan pendapatan agroindustri gula kelapa. Hasil penelitian ini sesuai dengan hasil penelitian dari Mumu (2015) dan Sudrajat dan Isyanto (2017). Semakin tinggi tingkat pendidikan, maka akan lebih mudah dalam menyerap inovasi teknologi (Elly dan Salendu, 2012). Pengetahuan yang diperoleh dari pendidikan formal tidak berkaitan dengan proses produksi gula kelapa. Oleh karena itu, perlu diberikan bimbingan teknis dan penyuluhan kepada pelaku agroindustri gula kelapa dalam upaya meningkatkan pendapatannya. 
Pengalaman $\left(\mathrm{X}_{5}\right)$ tidak berpengaruh signifikan terhadap pendapatan agroindustri gula kelapa. Koefisiensi regresi bertanda positif menunjukkan bahwa peningkatan pengalaman akan meningkatkan pendapatan agroindustri gula kelapa. Hasil penelitian ini menunjukkan bahwa semakin lama pengalaman dalam menjalankan agroindustri gula kelapa akan semakin menguasai keterampilan teknis dan manajemen yang diperlukan dalam mengelola agroindustri gula kelapa, sehingga pendapatan yang diperoleh akan meningkat.

Ukuran keluarga $\left(\mathrm{X}_{6}\right)$ tidak berpengaruh signifikan terhadap pendapatan agroindustri gula kelapa. Koefisiensi regresi bertanda negatif menunjukkan bahwa peningkatan ukuran keluarga akan menurunkan pendapatan agroindustri gula kelapa. Semakin besar ukuran keluarga maka akan semakin banyak kebutuhan hidup keluarga yang harus dipenuhi sehingga akan mencari penghasilan di luar agroindustri gula kelapa yang berdampak pada penurunan curahan waktu kerja pada agroindustri gula kelapa. Hal ini menyebabkan jumlah produksi yang dihasilkan tidak maksimal yang berdampak pada penurunan pendapatan.

Kredit $\left(\mathrm{X}_{7}\right)$ berpengaruh signifikan terhadap pendapatan agroindustri gula kelapa. Koefisiensi regresi bertanda negatif menunjukkan bahwa pendapatan pada agroindustri yang memiliki akses terhadap kredit lebih rendah dibandingkan dengan pendapatan pada agroindustri yang tidak memiliki akses terhadap kredit. Hasil penelitian ini sesuai dengan hasil penelitian dari Sudrajat dan Isyanto (2017). Agroindustri yang tidak memiliki akses terhadap kredit atau yang menggunakan modal sendiri akan lebih intens dalam mengelola usahanya sehingga produksi maksimal bisa tercapai yang berdampak pada pendapatan yang tinggi.

Penyuluhan $\left(\mathrm{X}_{8}\right)$ berpengaruh signifikan terhadap pendapatan agroindustri gula kelapa. Koefisiensi regresi bertanda negatif menunjukkan bahwa pendapatan pada agroindustri yang mengikuti penyuluhan lebih rendah dibandingkan dengan pendapatan pada agroindustri yang tidak mengikuti penyuluhan. Hal ini menunjukkan bahwa kegiatan pennyuluhan tidak mampu meningkatkan kemampuan teknis dan manajerial dari pelaku agroindustri. 


\section{Produktivitas Agroindustri Gula Kelapa}

Distribusi produktivitas faktor total yang dicapai pada agroindustri gula kelapa di Kabupaten Pangandaran dapat dilihat pada Tabel 4.

Tabel 4. Distribusi Produktivitas Agroindustri Gula Kelapa

\begin{tabular}{|c|c|c|c|}
\hline No & Produktivitas & $\begin{array}{l}\text { Jumlah } \\
\text { (orang) }\end{array}$ & $(\%)$ \\
\hline 1. & $<1,00$ & 14 & 14,00 \\
\hline 2. & 1,00 & 7 & 7,00 \\
\hline 3. & $>1,00$ & 79 & 79,00 \\
\hline \multicolumn{2}{|r|}{ Jumlah } & 100 & 100,00 \\
\hline $\begin{array}{l}\text { Min } \\
\text { Mak } \\
\text { Rata }\end{array}$ & $\begin{array}{l}\text { nun }=0,60 \\
\text { imum }=3,12 \\
\text { rata }=1,52\end{array}$ & & \\
\hline
\end{tabular}

Sumber: Analisis Data Primer, 2018

Produktivitas faktor total yang dicapai berkisar antara 0,60-3,12, dengan rata-rata sebesar 1,52. Agroindustri gula kelapa di Kabupaten Pangandaran yang mencapai produktivitas faktor total di bawah 1 (satu) sebanyak 14. Kegiatan penyuluhan dan bimbingan teknis seyogyanya difokuskan pada 14 agroindustri ini dalam upaya meningkatkan pendapatan agroindustri gula kelapa tersebut.

Peningkatan produktivitas tidak hanya dipengaruhi oleh tingkat penggunaan teknologi saja, namun kualitas input yang digunakan juga sangat signifikan berpengaruh terhadap produktivitas. Jika ada peningkatan kualitas input yang digunakan, maka pada tingkat penggunaan input yang sama dapat diproduksi lebih banyak output. Peningkatan kualitas output secara langsung akan menurunkan biaya produksi sehingga akan meningkatkan pendapatan (Othman dan Baharuddin, 2015).

\section{Faktor-faktor yang Berpengaruh Terhadap Produktivitas Agroindustri Gula Kelapa}

Analisis faktor-faktor yang berpengaruh terhadap produktivitas agroindustri gula kelapa dilakukan dengan menggunakan persamaan regresi linier berganda dimana pendugaan parameter dilakukan dengan menggunakan SPSS versi 16. Hasil analisis faktor-faktor yang berpengaruh terhadap produktivitas dapat dilihat pada Tabel 5.

Tabel 5 menunjukkan nilai $\mathrm{R}^{2}$ sebesar 0,897 yang menunjukkan bahwa variasi perubahan nilai produktivitas dipengaruhi sebesar $89,70 \%$ oleh variasi perubahan nilai variabel-variabel bebas yang dimasukkan ke dalam model; sedangkan sisanya sebesar $10,30 \%$ dipengaruhi oleh variabel lain yang tidak dimasukkan ke dalam model. 
Tabel 5. Faktor-faktor yang Berpengaruh Terhadap Produktivitas

\begin{tabular}{lccc}
\hline \multicolumn{1}{c}{ Variabel } & Nilai parameter & Standar deviasi & t-hitung \\
\hline Konstanta & $-11,259$ & 0,749 & $-15,037^{*}$ \\
Biaya produksi $\left(\mathrm{X}_{1}\right)$ & 0,929 & 0,049 & $18,951^{*}$ \\
Umur $\left(\mathrm{X}_{2}\right)$ & 0,120 & 0,087 & 1,374 \\
Pendidikan $\left(\mathrm{X}_{3}\right)$ & 0,290 & 0,076 & $3,797^{*}$ \\
Pengalaman $\left(\mathrm{X}_{4}\right)$ & $-0,045$ & 0,022 & $2,077^{*}$ \\
Ukuran keluarga $\left(\mathrm{X}_{5}\right)$ & 0,155 & 0,036 & $4,297^{*}$ \\
Kredit $\left(\mathrm{X}_{6}\right)$ & 0,137 & 0,051 & $2,668^{* *}$ \\
Penyuluhan $\left(\mathrm{X}_{7}\right)$ & 0,106 & 0,046 & $2,302^{* *}$ \\
\hline $\mathrm{R}^{2}=0,897$ & & & \\
F-hit $=114,918^{*}$ & & & \\
\hline
\end{tabular}

Sumber: Analisis Data Primer, 2018

Keterangan: $* * * * * *=$ signifikansi pada $1 \%, 5 \%, 10 \%$

Pengujian secara simultan dengan menggunakan uji $\mathrm{F}$ menunjukkan bahwa variabel biaya produksi $\left(\mathrm{X}_{1}\right)$, Umur $\left(\mathrm{X}_{2}\right)$, pendidikan $\left(\mathrm{X}_{3}\right)$, pengalaman $\left(\mathrm{X}_{4}\right)$, ukuran keluarga $\left(\mathrm{X}_{5}\right)$, kredit $\left(\mathrm{X}_{6}\right)$, dan penyuluhan $\left(\mathrm{X}_{7}\right)$ berpengaruh signifikan terhadap produktivitas yang dicapai pada agroindustri gula kelapa.

Pengujian secara parsial dengan menggunakan uji t menunjukkan bahwa variabel biaya produksi $\left(\mathrm{X}_{1}\right)$, pendidikan $\left(\mathrm{X}_{3}\right)$, pengalaman $\left(\mathrm{X}_{4}\right)$, ukuran keluarga $\left(\mathrm{X}_{5}\right)$, kredit $\left(\mathrm{X}_{6}\right)$, dan penyuluhan $\left(\mathrm{X}_{7}\right)$ berpengaruh signifikan terhadap produktivitas yang dicapai pada agroindustri gula kelapa. Sedangkan variabel umur $\left(\mathrm{X}_{2}\right)$ tidak berpengaruh signifikan terhadap produktivitas yang dicapai pada agroindustri gula kelapa.

Biaya produksi $\left(\mathrm{X}_{1}\right)$ berpengaruh signifikan terhadap produktivitas yang dicapai pada agroindustri gula kelapa. Koefisiensi regresi bertanda positif menunjukkan bahwa peningkatan biaya produksi akan meningkatkan produktivitas. Hasil penelitian Rustami, dkk. (2014) menunjukkan bahwa biaya produksi berpengaruh signifikan terhadap laba. Peningkatan biaya produksi akan meningkatkan jumlah produksi sehingga jumlah penerimaan juga akan meningkat. Peningkatan jumlah produksi ini akan meningkatkan produktivitas, ceteris paribus.

Umur $\left(\mathrm{X}_{2}\right)$ tidak berpengaruh signifikan terhadap produktivitas yang dicapai pada agroindustri gula kelapa. Koefisiensi regresi bertanda positif menunjukkan bahwa peningkatan umur akan meningkatkan produktivitas. Hasil penelitian ini sesuai dengan hasil penelitian yang dilakukan Isyanto (2014). 
Peningkatan umur akan meningkatkan keterampilan teknis dan manajerial yang diperlukan dalam upaya peningkatan produktivitas.

Pendidikan $\left(\mathrm{X}_{3}\right)$ berpengaruh signifikan terhadap produktivitas yang dicapai pada agroindustri gula kelapa. Koefisiensi regresi bertanda positif menunjukkan bahwa peningkatan pendidikan akan meningkatkan produktivitas. Hasil penelitian ini sesuai dengan hasil penelitian yang dilakukan Isyanto dan Nuryaman (2015) dan Rachmina, dkk. (2013). Peningkatan pendidikan formal membuat seseorang lebih terbuka terhadap inovasi teknologi yang diperlukan dalam peningkatan produktivitas.

Pengalaman $\left(\mathrm{X}_{4}\right)$ berpengaruh signifikan terhadap produktivitas yang dicapai pada agroindustri gula kelapa. Koefisiensi regresi bertanda negaif menunjukkan bahwa peningkatan pengalaman akan menurunkan produktivitas. Hasil penelitian ini sesuai dengan hasil penelitian yang dilakukan Rachmina, dkk. (2013) dan Isyanto (2014). Lamanya pengalamana semakin membuat seseorang nyaman dengan sistem produksi yang telah dilaksanakannnya sehingga relatif sulit dalam menerima inovasi yang diperlukan dalam upaya peningkatan produktivitas.

Ukuran keluarga $\left(\mathrm{X}_{5}\right)$ berpengaruh signifikan terhadap produktivitas yang dicapai pada agroindustri gula kelapa. Koefisiensi regresi bertanda positif menunjukkan bahwa peningkatan ukuran keluarga akan meningkatkan produktivitas. Hasil penelitian ini sesuai dengan hasil penelitian yang dilakukan Rachmina, dkk. (2013). Semakin besar ukuran keluarga maka akan semakin termotivasi dalam bekerja dalam upaya memenuhi kebutuhan hidup keluarganya sehingga produktivitasnya akan meningkat.

Kredit $\left(\mathrm{X}_{6}\right)$ berpengaruh signifikan terhadap produktivitas yang dicapai pada agroindustri gula kelapa. Koefisiensi regresi bertanda positif menunjukkan bahwa produktivitas yang dicapai pada agroindustri yang memiliki akses terhadap kredit lebih tinggi jika dibandingkan dengan agroindustri yang tidak memiliki akses terhadap kredit. Hasil penelitian ini sesuai dengan hasil penelitian yang dilakukan Sujarweni dan Utami (2015). Akses terhadap kredit akan meningkatkan investasi sehingga terjadi peningkatan skala produksi yang 
berdampak pada peningkatan jumlah produksi dan produktivitas.

Penyuluhan $\quad\left(\mathrm{X}_{7}\right)$ berpengaruh signifikan terhadap produktivitas yang dicapai pada agroindustri gula kelapa. Koefisiensi regresi bertanda positif menunjukkan bahwa produktivitas yang dicapai pada agroindustri yang mengikuti penyuluhan lebih tinggi jika dibandingkan dengan agroindustri yang tidak mengikuti penyuluhan. Hasil penelitian ini sesuai dengan hasil penelitian yang dilakukan Widodo dan Sunarso (2009), Kustiari, dkk. (2012), dan Bakhri dan Sudaryono (2016). Penyuluhan dapat meningkatkan keterampilan teknis dan memajerial yang diperlukan dalam pengelolaan usaha sehingga terjadi peningkatan produktivitas.

\section{PENUTUP}

Kesimpulan dari penelitian ini adalah: (1) Biaya total agroindustri gula kelapa di Kabupaten Pangandaran sebesar $\mathrm{Rp}$ 85.135,39, penerimaan $\mathrm{Rp}$ 113.232,00, dan pendapatan $\mathrm{Rp}$ 28.096,61. Jumlah produksi, modal, pendidikan, kredit, dan penyuluhan berpengaruh signifikan terhadap pendapatan agroindustri gula kelapa.
Sedangkan umur, pengalaman, dan ukuran keluarga tidak berpengaruh signifikan terhadap pendapatan agroindustri gula kelapa, dan (2) Produktivitas faktor total yang dicapai pada agroindustri gula kelapa di Kabupaten Pangandaran berkisar antara 0,60-3,12, dengan rata-rata sebesar 1,52. Biaya produksi, pendidikan, pengalaman, ukuran keluarga, kredit, dan penyuluhan berpengaruh signifikan terhadap produktivitas yang dicapai pada agroindustri gula kelapa. Sedangkan umur tidak berpengaruh signifikan terhadap produktivitas yang dicapai pada agroindustri gula kelapa.

Berdasar kesimpulan penelitian, maka diajukan saran sebagai berikut: (1) Perlu dipertimbangkan pemberian bantuan modal kepada agroindustri gula kelapa di Kabupaten Pangandaran melalui kredit program sehingga dapat ditingkatkan skala produksi dan pendapatannya, dan (2) Perlu dipertimbangkan kegiatan penyuluhan dan bimbingan teknis untuk meningkatkan keterampilan teknis dan manajerial sehingga dapat meningkatkan produktivitas dan pendapatan agroindustri gula kelapa di Kabupaten Pangandaran. 


\section{UCAPAN TERIMA KASIH}

Ucapan terima kasih disampaikan kepada Direktorat Jenderal Penguatan Riset dan Pengembangan, Kementerian Riset, Teknologi dan Pendidikan Tinggi, yang telah membiayai penelitian ini melalui skema Penelitian Dosen Pemula tahun anggaran 2018.

\section{DAFTAR PUSTAKA}

Aliudin, Sariyoga, S., dan Anggraeni, D. 2011. Efisiensi dan Pendapatan Usaha Gula Aren Cetak (Kasus pada Perajin Gula Aren Cetak di Desa Cimenga, Kecamatan Cijaku, Kabupaten Lebak, Provinsi Banten). Jurnal Agro Ekonomi, 29(1): 73-85.

Ariani, N.W.D., dan Suresmiathi, A.A.A. 2013. Pengaruh Kualitas Tenaga Kerja, Bantuan Modal Usaha dan Teknologi Teradap Produktivitas Kerja Usaha Mikro Kecil dan Menengah (UMKM) di Jimbaran. E-Jurnal EP Unud, 2(2): 102-107.

Bakhri, F.R. 2016. Faktor-faktor yang Mempengaruhi Produktivitas Usaha Tani Antara Kecamatan Peterongan dan Kecamatan Megaluh Kabupaten Jombang. Jurnal Pendidikan Geografi, 3(3): 416422.

Bakhri, F.R. dan Sudaryono, L. 2016. Faktor-Faktor yang Mempengaruhi Produktivitas Padi Antara Kecamatan Peterongan dan Kecamatan Megaluh Kabupaten Jombang. Jurnal Pendidikan Geografi, 3(3): 416-422.

Batubara, E.M., Rujiman, dan Rahmanta. 2014. Analisis Faktor-faktor yang Memengaruhi Pendapatan Petani
Gula Aren dan Pengembangannya pada Lahan Marginal di Kabupaten Tapanuli Selatan. Jurnal Ekonom 17(4) 162-173.

Budiarto. 2010. Pembangunan Ekonomi Perdesaan Melalui Agroindustri: Penentuan Prioritas Pengembangan Jenis Agroindustri Kelapa di Kabupaten Kulonprogo. SEPA 7(1): 1-71.

Butarbutar, G.R. 2017. Analisis Faktorfaktor yang Mempengaruhi Pendapatan Usaha Industri Makanan Khas di Kota Tebing Tinggi. JOM Fekon, 4(1): 619-633.

Coelli, T., Rao, D.S.P., O’Donnell, C.J., dan Battese, G.E. 2005. An Introduction to Efficiency and Productivity Analysis. Second Edition. New York: Springer.

Darma, R., Zain, A.M.M., dan Tenriawaru, A.N. 2015. Brown Cane Sugar-cattle Production Integration for Rural Economic Development Prospects in South Sulawesi, Indonesia. merican Journal of Experimental Agriculture 8(2): 107-119.

Elly, F.E., dan Salendu, A.H.S. 2012. Analisis ekonomi rumahtangga peternak sapi di Kecamatan Sinonsayang Kabupaten Minahasa. Jurnal Agribisnis dan Pembangunan Masyarakat 1(1): 19.

Evalia, N.A. 2015. Strategi Pengembangan Agroindustri Gula Semut Aren. Jurnal Manajemen \& Agribisnis, 12(1): 57-67.

Isyanto, A.Y. 2014. Kajian Produktivitas Usaha Penggemukan Sapi Potong di Kabupaten Ciamis. Prosiding Seminar Nasional Kedaulatan Pangan dan Pertanian. Jurusan Sosial Ekonomi Pertanian, Fakultas 
Pertanian, Universitas Gadjah Mada. pp. 559-567.

Isyanto, A.Y., dan Nuryaman, H. 2015. Faktor-faktor yang Berpengaruh Terhadap Produktivitas Usahatani Kedelai di Kabupaten Ciamis. Prosiding Seminar Nasional Agribisnis Kedelai. Magister Manajemen Agribisnis Fakultas Pertanian Universitas Gadjah Mada. pp. 1-7.

Khotimah, S., Kusmiati, A. dan Agustina, T. 2014. Analisis Pendapatan Pengrajin Gula Kelapa dan Kontribusinya Terhadap Pendapatan Keluarga di Desa Lojejer Kecamatan Wuluhan Kabupaten Jember. JSEP, 7(2): 4554.

Kiranasari, Y. 2011. Pengaruh Upah per bulan, Jenis Kelamin, dan Jumlah Tanggungan Keluarga Terhadap Curahan Jam Kerja Sektor Informal di Kabupaten Tegal. Jurnal Ilmu Ekonomi Pembangunan, 15(2).

Kustiari, T., Sumardjo, Slamet, M. dan Tjitropranoto, P. 2012. Pengaruh Efektivitas Penyuluhan Terhadap Kompetensi Pembudidaya Rumput Laut Polikultur di Perairan Pantai Utara Pulau Jawa. J. Sosek KP, 7(1): 79-95.

Maharani, E., Edwina, S., dan Kusumawaty, Y. 2011. Pemasaran Gula Kelapa di Kabupaten Indragiri Hilir Melalui Pendekatan Struktur, Perilaku \& Penampilan Pasar. Indonesian Journal of Agricultural Economics (IJAE) 2(1): 87-104.

Manulang, M. 2005. Dasar-Dasar Manajemen. Cetakan Pertama. Yogyakarta: Gadjah Mada University Press.

Martono, A., Budiningsih, S. dan Watemin. 2007. Analisis Kelayakan Ekonomi Agroindustri
Gula Kelapa di Desa Jalatunda Kecamatan Mandiraja. AGRITECH, IX(1): 1-21.

Masuku, M.B. 2011. Determinants of Sugarcane Profitability: The Case of Smallholder Cane Growers in Swaziland. Asian Journal of Agricultural Sciences 3(3): 210214.

Mugiono, Marwanti, S., dan Awami, S.N. 2014. Analisis Pendapatan Usaha Gula Merah Kelapa (Studi Kasus di Desa Medono Kecamatan Kaliwiro Kabupaten Wonosobo). Mediagro 10(2): 22-31.

Muhroil, Rochdiani, D. dan Pardani, C. 2015. Analisis Usaha Agroindustri Gula Kelapa (Suatu Kasus di Kecamatan Langensari Kota Banjar). Jurnal Ilmiah Mahasiswa AGROINFO GALUH, 1(3): 177182.

Mumu, A.R. 2015. Faktor-faktor yang Mempengaruhi Tingkat Pendapatan Wirausaha Masyarakat di Kelurahan Malalayang II. e-journal “Acta Diurna", IV(3): 1-5.

Nadiri, M.I. 1970. Some approaches to the theory and measurement of total factor productivity: a survey. Journal of Economic Literature VIII(4): 1137-1177.

Onumah, J.A., Al-Hassan, R.M., dan Onumah, E.E. 2013. Productivity and Technical Efficiency of Cocoa Production in Eastern Ghana. Journal of Economics and Sustainable Development 4(4): 106-117.

Othman, K. dan Baharuddin, A.H. 2015. The Total Factor Productivity in Strategic Food Crops Industry of Malaysia. Asian Journal of Agriculture and Rural Development, 5(5): 124-136. 
Purwanto, N.A. 2006. Kontribusi Pendidikan Bagi Pembangunan Ekonomi Negara. Jurnal Manajemen Pendidikan, 02(II): 17.

Putri, A.D. dan Setiawina, N.D. 2013. Pengaruh Umur, Pendidikan, Pekerjaan Terhadap Pendapatan Rumah Tangga Miskin di Desa Bebandem. E-Jurnal EP Unud, 2(4): 173-180.

Rachman, B. 2009. Karakteristik Petani dan Pemasaran Gula Aren di Banten. Forum Penelitian Agro Ekonomi 27(1): 53-60.

Rachmina, D., Daryanto, A., Tambunan, M., dan Hakim, D.B. 2013. Determinant factors of vegetable farm productivity in pangalengan, west java, indonesia. ASEAN Journal of Economics, Management and Accounting, I(2):95-105.

Rizieq, R. 2009. Analisis Produksi Gula Kelapa di Desa Peniti Luar Kecamatan Siantan. Jurnal Agrosains 6(1): 44-52.

Rusmiati, Bachri, S. dan Rismawati. 2011. Analisis Usaha Pembuatan Gula Merah di Kecamatan Sukamaju. Jurnal Equilibrium, 1(1): 66-77.

Saleh, Y. 2014. Analisis Pendapatan Usaha Pengrajin Gula Aren di Desa Tulo'a Kecamatan Bulango Utara Kabupaten Bone Bolango. Jurnal Perspektif Pembiayaan dan Pembangunan Daerah, 1(4): 219224.
Setiawan, J. 2012. Analisis Beberapa Faktor yang Mempengaruhi Tingkat Pendapatan Industri Kecil Sepatu Kulit di Kabupaten Magetan. Jurnal AKMENBIS, I(01): 1-20.

Singarimbun, M. 1989. Metode Penelitian Survai. Jakarta: LP3S.

Sudrajat dan Isyanto, A.Y. 2017. Faktorfaktor yang Berpengaruh Terhadap Pendapatan Usaha Ternak Ayam Sentul di Kabupaten Ciamis. Mimbar Agribisnis Jurnal Pemikiran Masyarakat Ilmiah Berwawasan Agribisnis, 4(1): 7083.

Sujarweni, V.W. dan Utami, L.R. 2015. Analisis Dampak Pembiayaan Dana Bergulir KUR (Kredit Usaha Rakyat) Terhadap Kinerja UMKM (Studi Kasus di Daerah Istimewa Yogyakarta). Jurnal Bisnis dan Ekonomi (JBE), 22(1): 1-24.

Supomo. 2007. Meningkatkan Kesejahteraan Pengrajin Gula Kelapa di Wilayah Kabupaten Purbalingga. Jurnal Ekonomi Pembangunan 12(2): 149-162.

Suratiyah, K. 2006. Ilmu Usahatani. Jakarta: Penebar Swadaya.

Triastono, H., Indraji, M., dan Mastuti, S. 2013. Pengaruh Faktor Sosial Ekonomi Terhadap Pendapatan dan Efisiensi Usaha Peternak Kelinci di Kabupaten Banyumas. Jurnal Ilmiah Peternakan, 1(1): 25-30.

Widodo dan Sunarso. 2009. Pengaruh Penyuluhan, Motivasi Dan Disiplin Kerja Terhadap Produktivitas Kerja Kelompok Tani. Jurnal Manajemen Sumberdaya Manusia, 3(1): 47-56. 